Jurnal Ilmu Komunikasi UHO : Jurnal Penelitian Kajian Ilmu Komunikasi dan Informasi.

Volume 6, No. 4, Oktober 2021, hlm 364-382

\title{
MAKNA GERAKAN SOSIAL MEME “JOKOWI: THE KING OF LIP SERVICE" PADA AKUN INSTAGRAM BEM UI
}

\author{
Nurdin Sibaweh, Hafied Cangara \\ Universitas Sahid, Jakarta, Indonesia \\ Sahid Sudirman Residence, Lt. 5 | Jl. Jenderal Sudirman No. 86, Jakarta 10220. \\ Universitas Hasanuddin, Makasar, Indonesia \\ J1. Perintis Kemerdekaan, Makasar, 90245 \\ nurdinsihermes@gmail.com
}

\begin{abstract}
ABSTRAK
Seiring perkembangan teknologi dan lahirnya media baru, gerakan sosial tidak hanya dalam bentuk aksi fisik dan gerakan massa dilapangan, melainkan mengambil bentuk-bentuk gerakan baru yang lebih variatif antara lain melalui media sosial, seperti meme di Instagram. Pada tanggal 26 Juni 2021, BEM UI melalui akun Instagram @bemui_official memosting meme "Jokowi: The King of Lip Service" yang viral di dunia maya dan mendapatkan reaksi dari pihak terkait dan respon yang luas dari publik. Penelitian ini bertujuan untuk mengkaji makna gerakan sosial politik meme "Jokowi: The King of Lip Service" dalam akun Instagram BEM UI, dengan menggunakan paradigma interpretatif dan pendekatan kualitatifdeskriptif. Adapun analisis yang akan digunakan yaitu teori semiotika Ferdinand de Saussure, melalui model utamanya, penanda (signifier) dan petanda (signified). Hasil penelitian menunjukkan bahwa meme tersebut merupakan gerakan sosial mahasiswa untuk mengkritik Presiden Jokowi atas tidak konsistennya ucapan, sikap dan kebijakan yang dikeluarkan. Hal itu antara lain ditunjukkan dalam kasus pelemahan KPK, revisi UU ITE, tindakan represif kepada demonstran, dan dicegatnya gugatan terhadap UU Cipta Kerja.
\end{abstract}

Kata Kunci: BEM UI, Gerakan sosial, Instagram, Jokowi. 
Jurnal Ilmu Komunikasi UHO : Jurnal Penelitian Kajian Ilmu Komunikasi dan Informasi.

Volume 6, No. 4, Oktober 2021, hlm 364-382

\begin{abstract}
Along with the development of technology and the emergence of new media, the form of social movement has also developed into not only physical action and mass movements on the street, but it has turned into new kind of actions with more varied forms of movement. such as movement through social media and memes on Instagram. On June 26, 2021, BEM UI through @bemui_official instagram account, had brought up the meme "Jokowi: The King of Lip Service" which went viral in cyberspace, this meme managed to attract reactions from related parties and also gained a wide response from the public. This study aims to examine the meaning of the socio-political movement of the meme "Jokowi: The King of Lip Service" uploaded by the BEM UI Instagram account, using an interpretive paradigm and a qualitativedescriptive approach. Ferdinand de Saussure's semiotic theory is used to analyze the case through its main model, the signifier and the signified. The results showed that the meme represented a student social movement to criticize President Jokowi for the inconsistent words, attitudes and policies issued. This inconsistency is shown, among others, in the case of weakening the KPK, the revision of the UU ITE, repressive actions against demonstrators, and the intercept of a lawsuit against the UU Cipta Kerja.
\end{abstract}

Keywords: BEM UI, Social movement, Instagram, Jokowi. 
Jurnal Ilmu Komunikasi UHO : Jurnal Penelitian Kajian IImu Komunikasi dan Informasi.

Volume 6, No. 4, Oktober 2021, hlm 364-382

\section{PENDAHULUAN}

Saat ini media menempati posisi yang sangat strategis, khususnya dikaitkan perkembangan teknologi informasi dan komunikasi (TIK) yang pada gilirannya memengaruhi bentuk media, dimana terdapat media lama dan media baru. Menurut Poster (dalam McQuail, 2011:151) media baru dapat dibedakan dari media lama, perbedaan tersebut terletak pada media baru yang tidak memiliki batasan dari aspek percetakan dan model penyiaran, setidaknya lima hal: (1) adanya kemungkinan adanya komunikasi antar-banyak pihak; (2) adanya kemungkinan terjadinya penerimaan secara simultan, dan perubahan, serta penyebaran kembali obyek-obyek budaya; (3) gangguan tindakan komunikasi dari posisi pentingnya, dari hubungan kewilayahan dan modernitas; (4) menyediakan secara instan kontak global; (5) masuknya subyek modern/akhir modern ke dalam mesin yang berjaringan.

Diantara bentuk media baru yaitu media sosial, antara lain Instagram. Menurut Talib dkk (dalam Arifuddin dan Irwansyah, 2019) Instagram diciptakan pertama kali oleh Mike Krieger dan Kevin Systrom. Situs resmi Instagram mendefinisikan Instagram sebagai aplikasi untuk berbagi foto dan video secara gratis bagi pengguna telepon seluler pintar, dan bisa membagikan juga foto atau video tersebut kepada teman dan pengikutnya, serta bisa berinteraksi dengan menyukai, melihat, dan memberikan komentar postingan yang dibagikan. Media sosial Instagram sendiri dibangun dengan teknologi Web 2.0 yang menjadikan penggunanya dapat menyediakan konten dan berbagi atas konten tersebut.

Pada laporan Digital 2021: The Latest Insights into the 'State of Digital' yang dirilis We Are Social dan Hootsuite, menunjukkan bahwa lima puluh persen penduduk di Indonesia menggunakan media sosial secara aktif, dari kurang lebih 274,9 juta jumlah penduduk di Indonesia, 170 juta di antaranya diketahui telah menggunakan media sosial. Adapun pengguna aktif media sosial di Indonesia pada Januari 2021 telah tumbuh sebesar 6,3 persen atau sekitar 10 juta pengguna aktif bila dibandingkan tahun sebelumnya yaitu bulan Januari 2020. Sementara dalam periode yang sama, pengguna internet di Indonesia mengalami peningkatan sebanyak 27 juta atau 15,5 persen, sehingga menjadi 202,6 juta. Dalam laporan tersebut, disebutkan juga bahwa rata-rata orang Indonesia menghabiskan 3 jam 14 menit sehari untuk mengakses media sosial, dan aplikasi yang paling banyak digunakan yaitu YouTube, disusul oleh WhatsApp, Instagram, Facebook, lalu Twitter (https://tekno.kompas.com, 24/2/2021). Berdasarkan laporan 
Jurnal Ilmu Komunikasi UHO : Jurnal Penelitian Kajian Ilmu Komunikasi dan Informasi.

Volume 6, No. 4, Oktober 2021, hlm 364-382

We Are Social dan Hootsuite tersebut, instagram merupakan media sosial urutan ketiga yang paling banyak digunakan orang Indonesia, dengan demikian termasuk salah satu yang terbanyak penggunanya.

Perkembangan media sosial, juga berdampak terhadap pemanfataannya, termasuk sebagai instrumen untuk melakukan gerakan sosial. Bahkan menurut Frederick (1993) dalam Rucht (2004:25), perkembangan TIK, khususnya internet, cenderung merevolusi strategi media gerakan sosial. Wim van de Donk dkk (2004:7) lebih jauh menjelaskan bahwa TIK dapat digunakan secara efektif tidak hanya untuk membangun dan memelihara organisasi yang kuat serta terpusat, melainkan juga dapat menjadi alat yang efektif untuk membangun dan menjalankan jaringan terdesentralisasi yang memungkinkan menyuarakan pandangan mereka, termasuk untuk memobilisasi komunitas baik secara virtual maupun fisik.

Menurut Rucht (2004:27) gerakan sosial adalah strive for change in society. Dalam proses upaya perubahannya, ada yang melakukan kontak pribadi dengan masyarakat untuk mengubah pikiran atau cara pandang agar bersama-sama melakukan perubahan, namun ada juga yang skeptis dengan cara tersebut lalu berpandangan agar perubahan dilakukan melalui perombakan struktur. Sementara Sztompka (2011) dalam Kapriani dan Lubis (2014) berpandangan bahwa gerakan sosial merupakan tindakan kolektif yang diorganisir secara longgar dan tanpa terlembaga secara formal yang diarahkan untuk menghasilkan perubahan dalam masyarakat.

Studi tentang gerakan sosial, menurut Mansour Fakih (1966:36) ada dua pendekatan yang saling bertentangan. Pertama adalah teori yang cenderung melihat gerakan sosial sebagai suatu gejala penyakit masalah kemasyarakatan, sehingga dianggap sebagai hal yang "negatif" karena menyebabkan konflik yang dapat merusak keharmonisan dalam masyarakat. Kedua adalah teoriteori ilmu sosial yang melihat hal sebaliknya, yaitu gerakan sosial sebagai "fenomena positif", atau bahkan konstruktif bagi perubahan sosial di masyarakat. Penelitian ini lebih diposisikan dalam pendekatan kedua, mengingat yang disorot dalam penelitian ini adalah gerakan mahasiswa. Nan Lin (dalam akbar, 2016) menjelaskan gerakan mahasiswa sebagai upaya kolektif untuk memajukan atau melakukan perubahan dalam sebuah masyarakat atau kelompok, dan ditegaskan oleh Nan Lin bahwa gerakan mahasiswa merupakan bagian dari gerakan sosial. Dalam konteks ini, Denny JA (Harian Kompas, 25/4/1998) menyatakan adanya tiga kondisi 
Jurnal Ilmu Komunikasi UHO : Jurnal Penelitian Kajian Ilmu Komunikasi dan Informasi.

Volume 6, No. 4, Oktober 2021, hlm 364-382

lahirnya gerakan sosial seperti gerakan mahasiswa. Pertama, dilahirkan oleh kondisi yang memberikan ruang dan kesempatan bagi gerakan itu, antara lain terkait dengan kekuasaan atau sistem pemerintahan yang ada. Kedua, timbulnya gerakan sosial karena meluasnya ketidakpuasan atas situasi yang ada di tengah-tengah masyarakat. Ketiga, lahirnya gerakan sosial dari kemampuan atas kepemimpinan tokoh penggeraknya yang memberikan inspirasi, membangun organisasi, dan membuat jaringan, sehingga melahirkan sekelompok orang atau masyarakat termotivasi untuk terlibat dan melakukan gerakan.

Gerakan sosial yang akan menjadi fokus penelitian adalah gerakan sosial melalui media sosial dalam bentuk meme "Jokowi: The King of Lip Service" yang diposting dalam akun Instagram @bemui_official pada tanggal 26 Juni 2021. Pada tanggal tersebut, BEM UI dalam akun instagramnya melakukan lima kali postingan. Pertama, postingan tentang informasi 'hari terakhir perekrutan terbuka staff GUIM 11 (Gerakan UI Mengajar 11); kedua, postingan tentang ucapan 'Selamat Hari Antinarkoba Internasional'; ketiga, postingan tentang informasi 'Telah Berlangsung: Peninjauan Asrama UI sebagai Tempat Karantina Covid-19'; keempat, postingan meme "Jokowi: The King of Lip Service"; kelima, postingan tentang informasi mengenai "Perekrutan Terbuka Staff UI Battlegrounds 2021".

Dari lima postingan tersebut di atas, yang akan diangkat dalam penelitian ini yaitu postingan keempat terkait meme "Jokowi: The King of Lip Service". Alasan mengangkat meme ini sebagai obyek penelitian, setidaknya terdapat tiga hal. Pertama, postingan meme tersebut mendapat respon langsung dari Presiden Jokowi. Dalam merespon meme tersebut Jokowi menyampaikan keterangan pers melalui YouTube Sekretariat Presiden tanggal 29 Juni 2021, sebagaimana dirilis beritanya oleh kompas.com, dimana Jokowi mengatakan "Ya itu kan sudah sejak lama ya, dulu ada yang bilang saya ini klemar-klemer, ada yang bilang juga saya itu plonga-plongo, kemudian ganti lagi ada yang bilang saya ini otoriter", Jokowi juga mengatakan "Kemudian ada juga yang ngomong saya ini bebek lumpuh, dan baru baru ini ada yang ngomong saya ini Bapak Bipang. Terakhir ada yang menyampaikan mengenai "The King of Lip Service". Beberapa kritikan dan julukan dari BEM UI tersebut, Jokowi kemudian menyebutnya sebagai bentuk ekspresi mahasiswa, dimana mengkritik boleh dilakukan di negara demokrasi, dan tidak perlu dihalangi. Akan tetapi, dalam menanggapi kritis tersebut, Jokowi juga mengingatkan mengenai budaya sopan santun dan tata krama. (https://nasional.kompas.com, 30/6/2021). 
Jurnal Ilmu Komunikasi UHO : Jurnal Penelitian Kajian Ilmu Komunikasi dan Informasi.

Volume 6, No. 4, Oktober 2021, hlm 364-382

Kedua, postingan meme tersebut mendapat respon dari pihak pimpinan Universitas Indonesia, dengan dipanggilnya ketua dan pengurus BEM UI pada hari Minggu tanggal 27 Juni 2021 melalui surat yang ditandatangani oleh Direktur Kemahasiswaan Universitas Indonesia, dengan nomor nomor: 915/UN2.RI.KMHS/PDP.00.04.00/2021 (https://www.cnnindonesia.com, 28/6/2021). Pemanggilan tersebut ditujukan kepada sepuluh mahasiswa pengurus BEM yang dipandang terlibat dalam lahirnya meme "Jokowi: King of Lip Service" dalam akun Instagram @bemui_official (https://megapolitan.kompas.com, 28/6/2021). Ketiga, adanya dukungan publik terhadap postingan meme tersebut, antara lain dukungan diberikan oleh BEM dari berbagai perguruan tinggi, seperti BEM Universitas Padjadjaran, BEM Universitas Yarsi, BEM Universitas Sriwijaya, dan Universitas Airlangga (https://www.cnnindonesia.com, 1/7/2021). Dukungan juga diberikan oleh akademisi, aktivis seperti Greenpeace Indonesia, Gusdurian Network Indonesia, Aliansi BEM Seluruh Indonesia, dan Pusako Fakultas Hukum Universitas Andalas (https://www.cnnindonesia.com, 28/6/2021). Berdasarkan tiga alasan di atas, postingan meme oleh BEM UI tersebut mendapatkan respon dari publik dan reaksi dari kekuasaan. Hal ini menunjukkan bahwa isu yang diangkat krusial dan memiliki dampak politik, meskipun hanya dilakukan melalui media sosial dalam bentuk meme.

Dalam Kamus Besar Bahasa Indonesia, meme didefinisikan sebagai cuplikan gambar dari film, acara televisi, dan sebagainya atau gambar-gambar yang dibuat sendiri lalu dimodifikasi dengan menambahkan kata-kata atau tulisan-tulisan untuk tujuan menghibur dan melucu (KBBI Daring). Menurut Allifiansyah (2016) meme pertama kali diperkenalkan oleh Richard Dawkins (1976) yang mengacu pada mutasi sebuah gen dalam menggandakan diri dan mereplikasi. Menurutnya, meme merupakan bentuk budaya yang ditransmisi melalui replikasi gagasan, ide, yang masuk ke dalam kognisi manusia. Konsep meme inilah yang selanjutnya diaplikasikan dalam konteks fenomena sosial, khususnya yang terjadi di internet. Dalam internet, meme dapat dimaknai sebagai bentuk replikasi seperti gambar, video, link ataupun lainnya. Bordie (2014, dalam Allifiansyah, 2016) menjelaskan bahwa meme terkait erat dengan proses replikasi beragam informasi dalam akal budi manusia, yang terkait dengan berbagai peristiwa sosial sehingga tercipta salinan meme lebih banyak.

Dalam perkembangannya, meme kemudian menjadi gaya komunikasi baru yang mampu mengandung muatan politik atau sebagai sarana yang dapat digunakan untuk mengkritisi kebijakan pemerintah atau elit negara. Oleh karena itu, fenomena meme tidak bisa dihindarkan 
Jurnal IImu Komunikasi UHO : Jurnal Penelitian Kajian Ilmu Komunikasi dan Informasi.

Volume 6, No. 4, Oktober 2021, hlm 364-382

menjadi sebuah bentuk demokrasi digital gaya baru yang sekaligus menunjukkan genre gaya berkomunikasi di era media baru sebagai wujud dari participatory digital culture (Wiggins \& Bowers, 2014, dalam Allifiansyah, 2016). Sementara menurut Ross dan Rivers (2019, dalam Purwaningrum dkk, 2020) meme di internet merupakan wujud perluasan bingkai di media yang sangat memiliki pengaruh terhadap fenomena tertentu. Selain itu, meme disampaikan juga dalam bentuk kreasi humor yang mampu menghidupkan aspirasi dan mewakili partisipasi sosial politik di ruang siber. Banyak hal yang dapat dikritisi melalui sebuah meme, dalam hal ini termasuk juga pejabat publik, pemerintah atau sosok Kepala Negara, dimana setiap langkah dan kebijakan yang dilakukannya tidak luput dari bidikan media sosial. Belakang ini, tepatnya akhir bulan Juni 2021 muncul meme "Jokowi: King of Lip Service" di akun Instagram @bemui_official yang menjadi perhatian warga net dan publik secara luas. Meme tersebut diunggah dalam akun resmi Instagram BEM UI sebagai lembaga eksekutif mahasiswa ditingkat Universitas Indonesia, dan BEM sendiri merupakan organisasi intra kampus. Meme tersebut, merupakan kritik BEM UI terhadap Presiden Jokowi, dan kritik ini dapat disebut sebagai gerakan sosial yang dilakukan mahasiswa melalui media sosial. Mengenai gerakan sosial melalui media sosial ini telah ada beberapa kajian dan penelitian yang relevan untuk mendukung penelitian ini.

Delfanti dan Arvidsson (2019:106) dalam buku Introduction to Digital Media, disalah satu sub-babnya, menjelaskan tentang gerakan sosial (social movement). Menurut Delfanti dan Arvidsson, merujuk Castells (2009), jika kekuatan politik terletak pada kemampuan untuk memprogram dan mengontrol jaringan, maka gerakan melawan kekuatan mapan atau bertindak untuk melakukan perubahan sosial, gerakannya harus mendasarkan pada upaya untuk memprogram ulang media digital. Bagi Delfanti dan Arvidsson, hal itu dilakukan dengan use them to communicate their contents and values by modifying their original purpose or finding new ways to exploit their technological and social characteristics. Oleh karena itu, media sosial merupakan bagian penting dari proses ini, karena mereka memastikan kemampuan yang lebih besar untuk bertindak secara independen, serbaguna, dan interaktif. Lebih jauh, media sosial memengaruhi partisipasi politik, karena mereka menurunkan biaya untuk mengakses politik. Bentuk aktivisme politik ini, menurut Bennett dan Segerberg (2012, dalam Delfanti dan Arvidsson, 2019:106) disebut sebagai connective action, yang sedang dalam proses menggantikan bentuk-bentuk tradisional aksi kolektif. 
Jurnal Ilmu Komunikasi UHO : Jurnal Penelitian Kajian IImu Komunikasi dan Informasi.

Volume 6, No. 4, Oktober 2021, hlm 364-382

Beberapa penelitian sebelumnya yang relevan dengan penelitian yang akan dilakukan peneliti antara lain penelitian Galuh (2016) dengan judul "Media Sosial sebagai Strategi Gerakan Bali Tolak Reklamasi menunjukkan" yang menunjukkan bahwa media sosial dapat menjadi suatu strategi gerakan sosial baru yang berperan untuk memfasilitasi strategi nalar dan refleksi dalam melakukan mobilisasi dukungan masyarakat. Dengan demikian media sosial memiliki kekuatan untuk mendorong representasi demokratis, jika mampu menjadi aksi nyata. Penelitian Galuh ini memfokuskan kepada isu lingkungan untuk menolak reklamasi di Bali, dengan menggunakan media sosial sebagai strategi gerakan sosial. Akan tetapi dalam penelitian Galuh ini, media sosial yang digunakan tidak spesifik media sosial Instagram, sebagaimana yang akan dilakukan oleh peneliti.

Penelitian lainnya dilakukan Purwaningrum dkk (2020) yang berjudul "Meme Sebagai Cerminan Berpikir Kritis Warganet Di Ruang Siber (Kajian Semiotik Pragmatik)". Penelitian ini menunjukkan bahwa meme-meme yang muncul sebagai reaksi warga net pasca pengumuman pemindahan Ibu Kota Negara dapat dilihat sebagai bentuk perkembangan berpikir kritis terhadap sebuah kebijakan pemerintah. Perbedaan penelitian ini jika dibandingkan dengan penelitian yang akan dilakukan oleh peneliti, yaitu konteks peristiwanya yang berbeda, meskipun sama-sama meneliti meme di media sosial Instagram.

Selanjutnya penelitian yang dilakukan Allifiansyah (2016) yang berjudul "Kamu Muda, Meme, dan Demokrasi Digital di Indonesia". Penelitian Allifiansyah ini memfokuskan pada peristiwa pada tahun 2014 mengenai kenaikan harga BBM dan keputusan DPR mengenai pilkada tak langsung, dengan menyorot meme-meme yang muncul pada dua media sosial yaitu Facebook dan Twitter. Penelitian ini sama-sama meneliti meme dalam media sosial. Namun yang membedakan penelitian yang akan dilakukan peneliti adalah media sosial Instagram dengan peristiwa janji-janji Jokowi.

Penelitian lain yang relevan yaitu penelitian yang dilakukan oleh Simarmata (2014) yang meneliti tentang media baru, ruang publik baru, dan transformasi komunikasi politik di Indonesia. Dalam penelitiannya, Simarmata menjelaskan bahwa media baru memberikan kontribusi bagi demokrasi yang cukup besar, antara lain dalam bentuk adanya ruang publik yang universal, dan bisa diakses oleh siapa saja. Dengan adanya ruang publik universal tersebut, masyarakat tidak mengalami hambatan dalam menyuarakan aspirasinya. Selain itu, media baru 
Jurnal Ilmu Komunikasi UHO : Jurnal Penelitian Kajian IImu Komunikasi dan Informasi.

Volume 6, No. 4, Oktober 2021, hlm 364-382

dapat mengubah komunikasi politik menjadi bottom up dan decentralized, dimana selama ini cenderung top-down. Dari penelitian Simarmata ini, perbedaan dengan penelitian yang akan dilakukan peneliti yaitu peneliti melakukan penelitian lebih spesifik dengan obyek media sosial Instagram sebagai salah salah bentuk media baru. Diantara hal yang dapat menjadi pijakan dan relevansi dari penelitian Simarmata ini adalah subtansi mengenai media baru yang dapat memberikan kontribusi bagi demokrasi.

Dari beberapa hasil penelitian tersebut di atas, terdapat perbedaan dengan penelitian yang akan dilakukan peneliti, dimana penelitian yang akan dilakukan peneliti akan fokus pada makna gerakan sosial meme "Jokowi: The King of Lip Service" di akun Instagram @bemui_official yang dikelola BEM UI dan diposting pada tanggal 26 Juni 2021. Peneliti akan menganalisis dengan menggunakan teori semiotika Ferdinand de Saussure. Menurut Piliang (2003: 44-46) dalam teori semiotika Saussure terdapat enam prinsip yang sangat mendasar. Pertama, prinsip struktural, yaitu suatu prinsip relasi tanda yang dipandang sebagai relasi struktural; kedua, prinsip kesatuan, yaitu suatu tanda dipandang sebagai kesatuan yang tidak dapat dipisahkan dari penanda (signifier) dan petanda (signified); ketiga, prinsip konvensional, yaitu suatu relasi struktural antara penanda (signifier) dan petanda (signified) yang bergantung pada kesepakatan sosial tentang bahasa (tanda dan makna) diantara komunitas bahasa; keempat, prinsip sinkronik, yaitu suatu prinsip relasi struktural yang dipandang sebagai sebuah kecenderungan kajian sinkronik, yaitu kajian tanda sebagai sistem yang tetap di dalam konteks waktu yang dipandang konstan, tidak berubah dan stabil; kelima, prinsip representasi, yaitu suatu prinsip relasi struktural dilihat sebagai sebuah bentuk representasi, dalam pengertian bahwa sebuah tanda merupakan representasi suatu realitas yang menjadi referensinya; keenam, prinsip kontinuitas, yaitu suatu prinsip dimana relasi antara sistem tanda dan penggunaannya secara sosial diposisikan sebagai sebuah continuиm atau disebut juga semiotic continuum.

Saussure (dalam Fiske,1990: 44) memahami tanda sebagai a physical object with a meaning yang terdiri dari penanda (signifier) dan petanda (signified). Penanda (signifier) adalah the sign's image as we perceive it-the marks on the paper or the sounds in the air. Adapun petanda (signified) adalah the mental concept to which it refers. Menurut Sobur (2004:125) kedua unsur ini (signifier dan signified) merupakan suatu kesatuan yang tidak dapat dipisahkan 
Jurnal IImu Komunikasi UHO : Jurnal Penelitian Kajian IImu Komunikasi dan Informasi.

Volume 6, No. 4, Oktober 2021, hlm 364-382

seperti selembar kertas atau dua sisi mata uang. Untuk melihatnya lebih operasional, kerangka semiotikanya Saussure dapat digambarkan sebagai berikut:

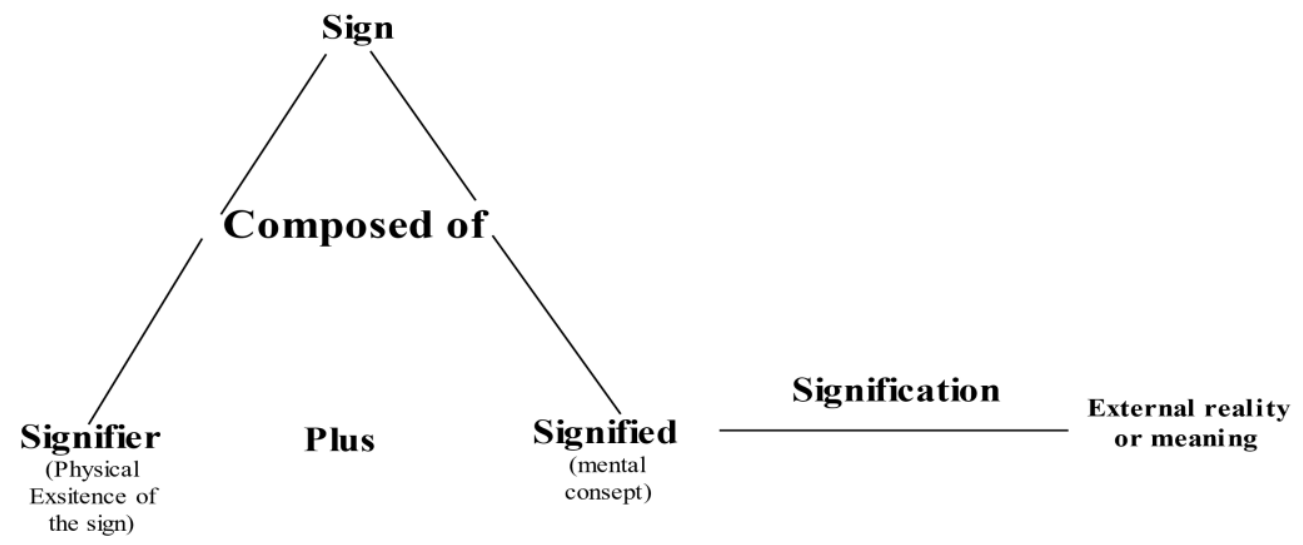

Sumber: John Fiske, dalam Introduction to Communication, 1990, h.44

Saussure menyebut signifier sebagai coretan atau bunyi bermakna, sementara signified adalah gambaran mental atau konsep dari signifier. Hubungan antara signifier dan signified dinamakan signification. Dengan kata lain, signification merupakan upaya dalam memberi makna terhadap dunia (Fiske,1990:44; Sobur,2004:125). Hasil dari upaya signification atas signifier dan signified itu disebut external reality or meaning. Konsep inilah yang secara operasional akan digunakan dalam penelitian ini, untuk pisau analisisnya. Setelah diketahui makna meme tersebut berdasarkan teori semiotika Saussure, maka makna-makna tersebut akan diletakkan atau dikaitkan dengan gerakan sosial. Sampai disini, maka penelitian ini bermaksud untuk menjawab permasalahan mengenai makna gerakan sosial politik meme "Jokowi: The King of Lip Service" pada akun Instagram @ bemui_official.

\section{METODE PENELITIAN}

Pada studi komunikasi penggunaan paradigma pada penelitian sangat penting perananya dalam mendapatkan data yang akurat. Paradigma yang akan digunakan dalam penelitian ini yaitu interpretif, dalam pengertian realitas sosial dipandang sebagai sesuatu yang komplek, holistik, dinamis, penuh makna dan hubungan gejala interaktif, yang berupaya menciptakan interpretasi 
Jurnal Ilmu Komunikasi UHO : Jurnal Penelitian Kajian IImu Komunikasi dan Informasi.

Volume 6, No. 4, Oktober 2021, hlm 364-382

(Ronda, 2018:23). Adapun metode yang digunakan yaitu kualitatif, dengan jenis penelitian yang digunakan yaitu deskriptif. Sementara analisis yang digunakan yaitu semiotika sebagai dasarnya, dengan model utama yang dikembangkan oleh Ferdinand De Saussure, penanda (signifier) dan petanda (signified). Dengan menggunakan model tersebut, peneliti bisa menganalisis makna dan tanda pesan pada akun instagram @bemui-official.

Objek penelitiannya difokuskan pada meme "Jokowi: The King of Lip Service" yang diposting oleh BEM UI pada akun instagramnya tanggal 26 Juni 2021. Data-data primer yang digunakan dalam penelitian ini didapatkan dari sumber yang amati, dan di catat pertama kalinya, data primer diambil dari meme "Jokowi: The King of Lip Service" pada akun Instagram @bemui-official. Adapun data sekunder bersumber dari jurnal, buku, artikel dan sumber lain yang mendukung penelitian ini. Teknik analisa data yang dilakukan ialah mengamati meme tentang "Jokowi: The King of Lip Service" pada akun Instagram @bemui_offical, dan selanjutnya memaknai komunikasi dalam bentuk penanda (signifier) dan petanda (signified) dari postingan meme tersebut sebagai gerakan sosial.

\section{HASIL DAN PEMBAHASAN}

\section{Postingan Meme "Jokowi: The King of Lip Service"}

Dalam pengamatan peneliti, sampai tanggal 26 Juli 2021, pukul 20.16, pengikut (followers) akun Instagram @ bemui_official berjumlah 166 ribu. Dalam akun Instagram tersebut diberikan keterangan "Akun resmi Instagram Badan Eksekutif Mahasiswa Universitas Indonesia". Pada tanggal 26 Juni 2021, Badan Eksekutif Mahasiswa Universitas Indonesia melalui akun Instagramnya memosting "Jokowi: The King of Lip Service" dimana dalam postingan gambarnya terdapat meme-meme tentang Jokowi. Postingan meme tersebut telah mendapatkan komentar sebanyak 35.230, dengan beragam komentar yang diberikan. Namun secara umum, komentar tersebut berisi tentang apresiasi dan dukungan terhadap BEM UI atas keberaniannya melakukan kritik dalam bentuk meme di media sosial. Meskipun ada beberapa komentar yang tidak mendukung, dan justru sebaliknya mengkritik BEM UI. Dalam postingan tersebut, terdapat delapan gambar, namun untuk kepentingan penelitian ini, terdapat tiga gambar yang akan diteliti. 
Jurnal IImu Komunikasi UHO : Jurnal Penelitian Kajian Ilmu Komunikasi dan Informasi.

Volume 6, No. 4, Oktober 2021, hlm 364-382

\section{Meme "Jokowi: The King of Lip Service"}

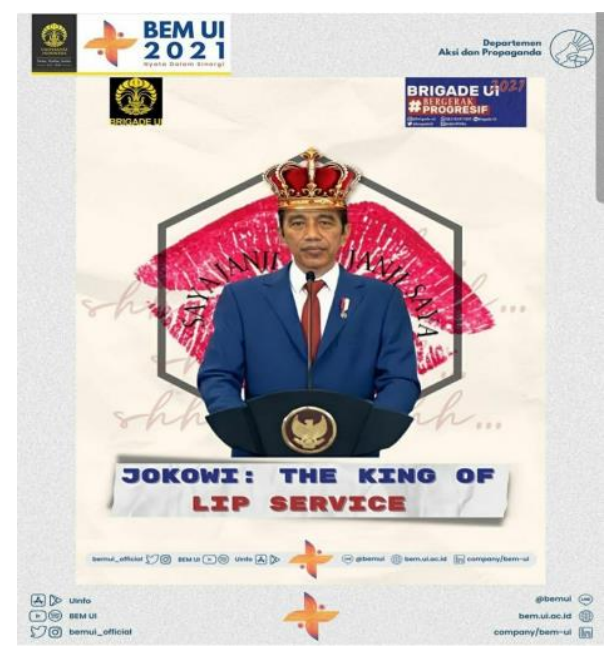

Gambar 1

(sumber: Akun Instagram @bemui_official)

\begin{tabular}{|l|l|}
\hline Penanda (Signifier) & Petanda (Signified) \\
\hline $\begin{array}{l}\text { Tercantum Foto Jokowi menggunakan jas } \\
\text { warna biru dan berdasi, dengan menggunakan } \\
\text { mahkota dan berdiri di atas podium presiden } \\
\text { dengan lambang garuda di bagian atas depan } \\
\text { podiumnya. }\end{array}$ & $\begin{array}{l}\text { Dapat dipahami sebagai seorang raja yang } \\
\text { sedang menyampaikan pidato disinggasananya }\end{array}$ \\
\hline $\begin{array}{l}\text { Dibelakang Jokowi terdapat gambar bibir } \\
\text { warna merah yang tertulis 'Saya Janji' pada } \\
\text { sebelah kanan, dan tertulis 'Janji saya' pada } \\
\text { sebelah kiri. }\end{array}$ & $\begin{array}{l}\text { Dapat dipahami seorang yang raja yang } \\
\text { berjanji (saya janji) namun perbuatannya tidak } \\
\text { sesuai dengan janji tersebut (janji saya) }\end{array}$ \\
\hline $\begin{array}{l}\text { Tertulis "JOKOWI: THE KING OF LIP } \\
\text { SERVICE", dengan tulisan "JOKOWI: THE } \\
\text { KING OF" berwarna biru, dan tulisan "LIP } \\
\text { SERVICE" berwarna merah. }\end{array}$ & $\begin{array}{l}\text { Ucapan atau janji Jokowi sebagai seorang } \\
\text { pemimpin hanya dibibir saja, berpura-pura } \\
\text { atau tidak jujur. }\end{array}$ \\
& $\begin{array}{l}\text { Tulisan "Jokowi: The King of" berwarna biru } \\
\text { menunjukkan ketenangan atau bersikap dingin. } \\
\text { Sementara tulisan "Lip Service" berwarna } \\
\text { merah dapat dipahami sebagai warna bibir } \\
\text { yang menunjukkan hanya sekadar diucapkan, } \\
\text { atau warna ini menunjukkan partai politik } \\
\text { pendukung utama Jokowi. Dengan demikian, } \\
\text { secara umum dapat dipahami ucapan dan janji } \\
\text { Jokowi disampaikan dengan tenang meskipun } \\
\text { hanya sekadar lip service. }\end{array}$ \\
\hline
\end{tabular}


Jurnal IImu Komunikasi UHO : Jurnal Penelitian Kajian Ilmu Komunikasi dan Informasi.

Volume 6, No. 4, Oktober 2021, hlm 364-382

Dari proses signification makna penanda dan petanda gambar ini, maka external reality meme "Jokowi: The King of Lip Service" menunjukkan bahwa Presiden Jokowi sering menyampaikan janji-janjinya, akan tetapi janji-janji tersebut hanya dibibir saja, atau hanya berpura-pura dan tidak jujur. Hal ini ditunjukkan dengan petanda non-verbal dalam bentuk bibir warna merah, dan petanda verbal frasa "saya janji" dan "janji saya" serta diperkuat dengan kalimat "Jokowi: The King of Lip Service". Frasa "saya janji" dan "janji saya" secara bahasa sama-sama bicara tentang janji, namun memiliki perbedaan penekanan. Frasa "saya janji" lebih menekankan pada pelakunya yang mengucapkan janji atau orangnya yang berjanji, sementara frasa "janji saya" lebih menekankan bentuk janjinya atau apa yang dijanjikan. Kedua frasa tersebut yang diletakkan terpisah namun tetap di depan gambar bibir warna merah memiliki pengertian bahwa adanya ketidaksesuain antara Presiden Jokowi yang berjanji dengan apa yang dijanjikannya. Adapun kalimat "Jokowi: The King of Lip Service" yang dalam bahasa Indonesia dapat diartikan Jokowi sebagai raja basa-basi, semakin menegaskan makna meme tersebut bahwa ucapan dan janji-janji Jokowi sebagai Presiden hanya basa-basi dan tidak sesuai dengan perbuatan atau implementasi kebijakannya.

\section{Penegasan BEM UI agar Jokowi berhenti membual karena rakyat sudah tidak percaya}

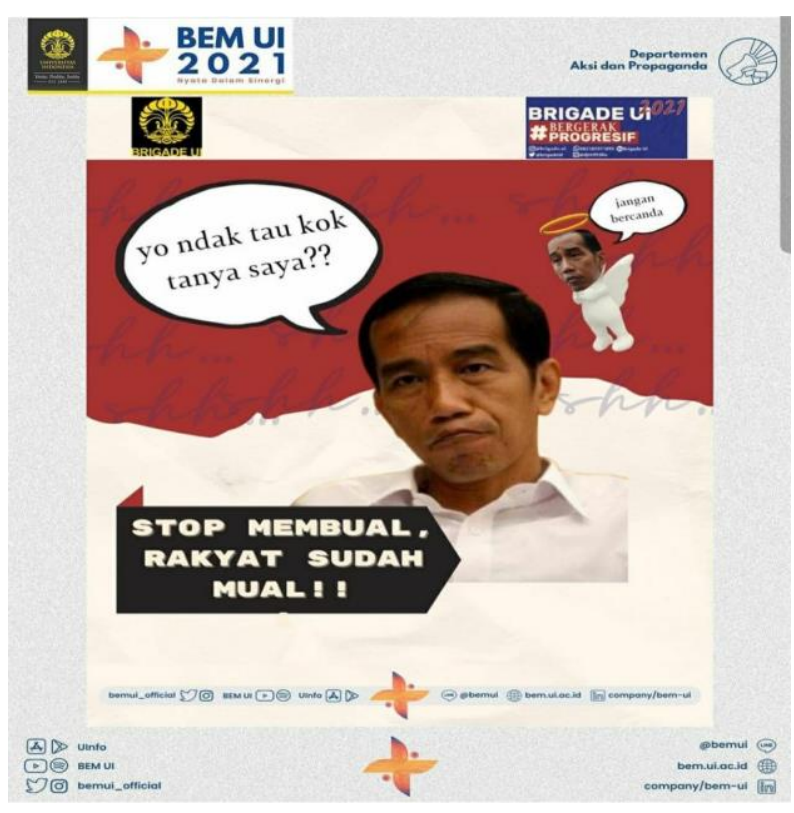

Gambar 2

(sumber: Akun Instagram @bemui_official) 
Jurnal Ilmu Komunikasi UHO : Jurnal Penelitian Kajian Ilmu Komunikasi dan Informasi.

Volume 6, No. 4, Oktober 2021, hlm 364-382

\begin{tabular}{|c|c|}
\hline Penanda (Signifier) & Petanda (Signified) \\
\hline $\begin{array}{l}\text { Tertulis "STOP MEMBUAL, RAKYAT } \\
\text { SUDAH MUAL!!” }\end{array}$ & $\begin{array}{l}\text { Dapat dipahami bahwa Jokowi sering } \\
\text { memberikan janji yang tidak ditepatinya, dan } \\
\text { rakyat sudah mual atau bosan dengan janji- } \\
\text { janjinya. }\end{array}$ \\
\hline $\begin{array}{l}\text { Terdapat foto Jokowi menggunakan baju } \\
\text { putik dengan bibirnya yang akan mengkerut, } \\
\text { sambil memgucapkan "yo ndak tahu kok } \\
\text { nanya saya??" }\end{array}$ & $\begin{array}{l}\text { Dapat dipahami bahwa Jokowi sering } \\
\text { menghindar dengan mengatakan tidak tahu } \\
\text { atas janji-janji yang telah disampaikan, ketika } \\
\text { janji tersebut diminta untuk ditunaikan, atau } \\
\text { atas kebijakan yang dinilai tidak sesuai dengan } \\
\text { janjinya. }\end{array}$ \\
\hline $\begin{array}{l}\text { Terdapat foto Jokowi dengan ukuran lebih } \\
\text { kecil menggunakan kostum warna putih yang } \\
\text { bisa untuk terbang dengan mengucapkan } \\
\text { "jangan bercanda". }\end{array}$ & $\begin{array}{l}\text { Dapat dipahami, Jokowi sering mengucapkan } \\
\text { janji tapi dengan gampang meninggalkan atau } \\
\text { melupakannya. Sementara frasa "jangan } \\
\text { bercanda" dapat dipahami Jokowi tidak } \\
\text { mengakui kalau dirinya dibilang pembual. }\end{array}$ \\
\hline $\begin{array}{l}\text { Terdapat gambar Bendera Merah Putih, yan } \\
\text { menjadi latar belakang foto Jokowi }\end{array}$ & $\begin{array}{l}\text { Dapat dipahami bahwa Bendera Merah Putih } \\
\text { merupakan bendera Negara Republik } \\
\text { Indonesia, dimana Jokowi sebagai Kepala } \\
\text { Negara harus teguh untuk menjunjung tinggi } \\
\text { nilai-nilai yang terkandung dalam bendera } \\
\text { tersebut, yaitu nilai-nilai keberanian dan } \\
\text { kesucian, termasuk juga kejujuran. }\end{array}$ \\
\hline
\end{tabular}

Dari proses signification makna penanda dan petanda gambar ini, maka external realitynya menunjukkan bahwa Jokowi sering memberikan janji yang tidak ditepatinya, atau menghindar ketika janji-janji tersebut dituntut untuk ditunaikan, sehingga rakyat tidak percaya lagi dengan janji Jokowi. Bahkan lebih jauh dipahami Jokowi tidak menjunjung tinggi nilai-nilai yang terkandung dalam Bendera Merah Putih sebagai bendera Negara Republik Indonesia, yaitu nilai-nilai keberanian dan kesucian, termasuk juga kejujuran. Selain itu, menurut Rahmawati (2020) Bendera Merah Putih merupakan bagian dari identitas masyarakat Indonesia dan telah mengintegrasikan beragam suku, agama, ras, dan adat istiadat di Indonesia, sehingga menjadikan Indonesia sebagai negara kesatuan. Dengan demikian mengabaikan nilai-nilai Bendera Merah Putih sebagai bendera Negara Republik Indonesia dan sekaligus identitas masyarakat Indonesia, maka dapat berpotensi merusak kesatuan bangsa. 
Jurnal IImu Komunikasi UHO : Jurnal Penelitian Kajian IImu Komunikasi dan Informasi.

Volume 6, No. 4, Oktober 2021, hlm 364-382

\section{Referensi BEM UI dalam menyampaikan kritik terhadap Presiden Jokowi}

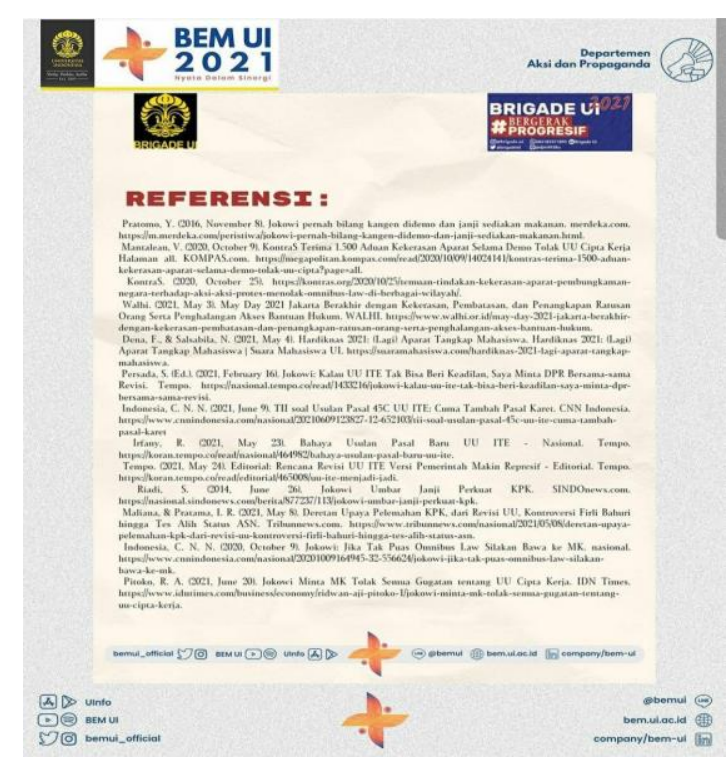

Gambar 3

(sumber: Akun Instagram @bemui_official)

Gambar 3 ini berisi daftar referensi yang digunakan BEM UI untuk mengkritik poin-poin lip service-nya Presiden Jokowi. Penanda (signifier) dalam gambar ini secara jelas dicantumkannya 13 (tiga belas) referensi yang digunakan sebagai rujukan atau dasar dari poinpoin kritik yang disampaikan BEM UI kepada Presiden Jokowi. Adapun petanda (signified) dalam gambar 3 dapat dipahami sebagai bukti bahwa kritikan yang dilakukan oleh BEM UI memiliki landasan, bukan sekadar isu yang dibuat-buat oleh BEM UI. Dari proses signification makna penanda dan petanda gambar ini, maka external reality-nya menunjukkan bahwa tidak sesuainya janji-janji Jokowi dengan perbuatan atau kebijakannya, memiliki landasan dengan dicantumkannya 13 (tiga belas) pemberitaan mengenai poin-poin yang di kritik BEM UI.

Dari seluruh postingan meme "Jokowi: The King of Lip Service" pada tanggal 26 Juni 2021 terdapat keterangan atau catatan yang diberikan oleh pengelola akun Instagram @bemui_official, yaitu: 
Jurnal Ilmu Komunikasi UHO : Jurnal Penelitian Kajian Ilmu Komunikasi dan Informasi.

Volume 6, No. 4, Oktober 2021, hlm 364-382

Halo, UI dan Indonesia!

Jokowi kerap kali mengobral janji manisnya, tetapi realitanya sering kali juga tak selaras. Katanya begini, faktanya begitu. Mulai dari rindu didemo, revisi UU ITE, penguatan KPK, dan rentetan janji lainnya. Semua mengindikasikan bahwa perkataan yang dilontarkan tidak lebih dari sekadar bentuk "lip service" semata.

Berhenti membual, rakyat sudah mual!

Brigade UI 2021

\#Bergerak Progresif

Diteruskan oleh

Departemen Aksi dan Propaganda

BEM UI 2021

Narahubung: Fathan (LINE: fathan_mubina30)

BEM UI 2021

\#NyataDalamSinergi

\#DepartemenAksidanPropagandaBEMUI2021

Keterangan atau catatan ini merupakan penanda verbal, dimana petandanya dapat dipahami bahwa BEM UI melalui Brigadenya menyampaikan kritik kepada Presiden Jokowi yang suka mengobral janji, tetapi janjinya tidak sesuai dengan kebijakannya. Kalimat "Halo, UI dan Indonesia!" menunjukkan bahwa obyek yang disapa adalah keluarga besar sivitas akademika Universitas Indonesia secara khusus, dan masyarakat atau bangsa Indonesia secara umum. Adapun yang dikritik BEM UI yaitu: 1) tindak represif kepada para demonstran, padahal Jokowi pernah mengatakan rindu di demo dan apabila didemo akan diajak masuk ke Istana untuk dialog; 2) usulan revisi UU ITE yang diucapkan oleh Jokowi untuk memberikan rasa keadilan, akan tetapi usulan revisi justru terdapat pasal karet yang berpotensi untuk digunakan melakukan tindakan represif; 3) Jokowi ingin memperkuat KPK, namun yang terjadi secara perlahan melakukan pelemahan terhadap Komisi Pemberantasan Korupsi yang mulai dari revisi terhadap UU KPK, lalu kontroversi terpilihnya Firli Bahuri sebagai ketua KPK dan adanya Tes Wawasan Kebangsaan (TWK) terkait alih status pegawai KPK. 
Jurnal IImu Komunikasi UHO : Jurnal Penelitian Kajian Ilmu Komunikasi dan Informasi.

Volume 6, No. 4, Oktober 2021, hlm 364-382

\section{SIMPULAN}

Media sosial Instagram telah digunakan dan dimanfaatkan oleh Badan Eksekutif Mahasiswa Universitas Indonesia sebagai media untuk melakukan gerakan sosial dalam bentuk kritik terhadap Presiden Jokowi yang dinilai tidak konsisten antara ucapan atau janji dengan kebijakan yang disampaikannya. Ucapan atau janji yang dinilai tidak konsisten dengan kebijakannya tersebut meliputi masih adanya tindakan represif kepada demonstran padahal Jokowi minta didemo dan demonstran akan diajak dialog, usulan revisi UU ITE yang justru berpotensi digunakan untuk melakukan tindakan represif padahal janjinya untuk memberikan rasa keadilan, dan pelemahan KPK padahal janjinya akan diperkuat. Meme "Jokowi: The King of Lip Service” yang diposting pada akun Instagram @bemui_official disebut sebagai gerakan sosial karena BEM UI mengharapkan adanya perubahan dari Presiden Jokowi agar konsisten dengan janji-janjinya dan ucapannya tidak hanya sekadar basa-basi alias lip service semata.

Gerakan sosial yang dilakukan BEM UI dengan memosting meme "Jokowi: The King of Lip Service" pada akun Instagramnya telah menjadi pemantik dari gerakan mahasiswa yang selama ini dipandang kurang bersuara terhadap kebijakan-kebijakan pemerintah. Oleh karena itu, peneliti memberikan saran, penelitian ke depan diharapkan ada yang meneliti mengenai dampak gerakan sosial BEM UI bagi gerakan mahasiswa dan juga dampaknya terhadap kebijakan Presiden Jokowi. 
Jurnal IImu Komunikasi UHO : Jurnal Penelitian Kajian Ilmu Komunikasi dan Informasi.

Volume 6, No. 4, Oktober 2021, hlm 364-382

\section{DAFTAR PUSTAKA}

Arifuddin, M Rizqi., \& Irwansyah (2019) Dari Foto Dan Video Ke Toko: Perkembangan Instagram Dalam Perspektif Konstruksi Sosial. Jurnal Komunikasi dan Kajian Media, Vol. 3, No. 1, 37-55, http://dx.doi.org/10.31002/jkkm.v3i1.1256

Akbar, Idil. (2016) Demokrasi dan Gerakan Sosial (Bagaimana Gerakan Mahasiswa terhadap Dinamika Perubahan Sosial). Jurnal Wacana Politik. Vol. 1, No. 2, 107-115, https://doi.org/10.24198/jwp.v1i2.11052.

Allifiansyah, Sandy. (2016) Kaum Muda, Meme, dan Demokrasi Digital di Indonesia. Jurnal Ilmu Komunikasi, Vol.13, No.2, 151-164, DOI:10.24002/jik.v13i2.676

Wim van de Donk, Brian D. Loader, Paul G. Nixon, \& Dieter Rucht. (Ed). (2004) Cyberprotest, New Media, Citizens and Social Movements, London and New York: Routledge.

Delfanti, Alessandro., \& Arvidsson, Adam. (2019) Introduction to Digital Media, USA: John Wiley \& Sons, Inc.

Fakih, Mansour. (1966) Masyarakat Sipil untuk Transformasi Sosial, Yogyakarta: Pustaka Pelajar.

Fiske, John. (1990) Introduction to Communication, Second edition, London: Methuen \& Co. Ltd.

Galuh, I Gusti Agung Ayu Kade. (2016) Media Sosial sebagai Strategi Gerakan Bali Tolak Reklamasi menunjukkan. Jurnal Ilmu Komunikasi, Vol.13, No.1, 73-92, https://doi.org/10.24002/jik.v13i1.602

JA, Denny. (1998) Menjelaskan Gerakan Mahasiswa, Harian Kompas, 25 April 1998

Kapriani, Dea Rizki., \& Lubis, Djuana P. (2014) Efektivitas Media Sosial Untuk Gerakan Sosial Pelestarian Lingkungan. Sodality: Jurnal Sosiologi Pedesaan, Vol. 2, No.3, 160-170.

KBBI Daring, https://kbbi.kemdikbud.go.id/entri/meme, diakses 27 Juli 2021

McQuail, Denis. (2011) Teori Komunikasi Massa, Jakarta: Salemba Humanika

Nur Hakim, Rahmat. (2021, Juni) Saat Jokowi Merespons Berbagai Kritik, dari Disebut "The King of Lip Service" hingga "Mencla-mencle", diakses 26 Juli 2021, dari https://nasional.kompas.com/read/2021/06/30/09581621/saat-jokowi-merespons-berbagai-kritikdari-disebut-the-king-of-lip-service?page=all

Piliang, Yasraf Amir. (2003) Hipersemiotika, Tafsir Cultural Studies Atas Matinya Makna, Bandung: Jalasutra.

Purwainingrum, Prapti Wigati., Saifullah, Aceng Ruhendi., \& Sudana, Dadang. (2020) Meme Sebagai Cerminan Berpikir Kritis Warganet Di Ruang Siber (Kajian Semiotik Pragmatik). Jurnal Dieksis, Vol. 12, No.3, 270-279, DOI: 10.30998/deiksis.v12i03.5417

Rucht, Dieter. (2004) The Quadruple 'A' Media Strategies of Protest Movements since the 1960s, in Cyberprotest, New media, citizens and social movements, Edited. by Wim van de Donk, Brian D. Loader, Paul G. Nixon, Dieter Rucht, London and New York: Routlegde.

Ronda, Andi Mirza. (2018) Tafsir Kontemporer Komunikasi, Tinjauan Teoritis, Epsitemologi, Aksiologi, Tangerang: Indigo Media

Rahmawati, Melinda. (2020) Makna Bendera Merah Putih Bagi Generasi Muda: Tinjauan Sejarah dari Masa Kerajaan Majapahit. Chronologia: Journal of History Education, Vol. 2, No. 1, 44, 36-45, http://dx.doi.org/10.22236/jhe.v2i1.5500

Ramai-ramai BEM Dukung BEM UI kritik Jokowi. (2021, Juli), diakses 26 Juli 2021, dari https://www.cnnindonesia.com/nasional/20210701065353-20-661582/ramai-ramai-bem-dukungbem-ui-kritik-jokowi

Ramai-ramai Dukung BEM UI Kritik Jokowi King of Lip Servive. (2021, Juni) diakses 27 Juli 2021, https://www.cnnindonesia.com/nasional/20210628134248-32-660320/ramai-ramai-dukung-bemui-kritik-jokowi-king-of-lip-service/2

Sobur, Alex. (2004) Analisis Teks Media, Suatu Pengantar untuk Analisis Wacana, Analisis Semiotik, dan Analisis Framing, Bandung: Remaja Rosda Karya. 
Jurnal IImu Komunikasi UHO : Jurnal Penelitian Kajian Ilmu Komunikasi dan Informasi.

Volume 6, No. 4, Oktober 2021, hlm 364-382

Simarmata, Salvatore. (2014) Media Baru, Ruang Publik Baru, Dan Transformasi Komunikasi Politik Di Indonesia, Interact, Vol. 3, No. 2,18 - 36, http://dx.doi.org/10.36388\%2Fia.v3i2.721

Stephanie, Coney. (2021, Februari) Riset Ungkap Lebih dari Separuh Penduduk Indonesia "Melek" Media Sosial, diakses 25 Juli 2021, dari https://tekno.kompas.com/read/2021/02/24/08050027/riset-ungkap-lebih-dari-separuh-pendudukindonesia-melek-media-sosial

Vitorio, Mantalean. (2021, Juni) Panggil BEM karena Bikin Meme "Jokowi: King of Lip Service", UI Anggap Presiden Simbol Negara, diakses 25 Juli 2021, dari https://megapolitan.kompas.com/read/2021/06/28/06592141/panggil-bem-karena-bikin-memejokowi-king-of-lip-service-ui-anggap

@bemui_official, akun resmi Instagram Badan Eksekutif Mahasiswa Indonesia 